\title{
Evaluation of the relationship between uric acid and bone mineral density in postmenopausal women: a single center retrospective study
}

\author{
Postmenopozal kadınlarda ürik asit ile kemik mineral yoğunluğu arasındaki \\ ilişkinin değerlendirilmesi: tek merkezli retrospektif çalışma
}

\author{
๑DErdal Dilekçi ${ }^{1}$, ĐEsra Nur Ademoğlu Dilekçi ${ }^{2}$ \\ ${ }^{1}$ Department of Physical Medicine and Rehabilitation, Bolu İzzet Baysal Physical Medicine and Rehabilitation Training and Research Hospital, Bolu, Turkey \\ ${ }^{2}$ Department of Endocrinology and Metabolism, Bolu Abant İzzet Baysal University Faculty of Medicine, Bolu, Turkey
}

Cite this article as/Bu makaleye atıf için: Dilekçi E, Ademoğlu Dilekçi EN. Evaluation of the relationship between uric acid and bone mineral density in postmenopausal women: a single center retrospective study. J Health Sci Med 2020; 3(4): 415-420.

\begin{abstract}
Objectives: Osteoporosis is an important public health problem which is characterized by loss of bone mass resulting in susceptibility to fractures. There is much evidence indicating that uric acid, a final enzymatic product of purine metabolism, has beneficial antioxidant effects on several chronic diseases such as diabetes mellitus, hypertension and cardiovascular diseases. We aimed to evaluate the relationship between serum uric acid levels and bone mineral density (BMD) on postmenopausal osteoporosis in the present study.

Material and Method: This study was carried out at the Bolu İzzet Baysal Physical Medicine and Rehabilitation Training and Research Hospital, Department of Physical Medicine and Rehabilitation. The medical records of 1200 postmenopausal women between January 2019 and 2020 who had dual energy x-ray absorptiometry (DEXA) examination and serum uric acid levels recorded were screened retrospectively. In total, 92 individuals with osteoporosis and 399 healthy individuals were included in the study after exclusion of subjects with systemic diseases or taking drugs affecting bone metabolism or uric acid levels. Bone mineral density and T scores of femur neck (F neck) and lumbar spine (L2-L4), glucose, AST, ALT, creatinine, alkaline phosphatase, calcium, phosphate, parathormone (PTH), albumin and total protein were all recorded in individuals.

Results: Serum uric acid concentrations were found to be significantly lower in the osteoporosis group compared with the control group [4.65(2.40-7.80) vs $5.20(3.80-9.40) ; \mathrm{p}<0.001$, respectively]. In correlation analysis, uric acid was significantly associated with fasting blood glucose $(\mathrm{r}=0.129, \mathrm{p}=0.004)$, creatinine $(r=0.374, p<0.001)$, calcium $(r=0.201, p<0.001)$, total protein $(r=0.123, p=0.006)$ and TSH $(r=0.108, p=0.017)$. Correlation analysis also revealed a significant and positive correlation between uric acid and L2-L4 BMD ( $r=0.255, \mathrm{p}<0.001)$. L2-L4 BMD was found to be independently related with uric acid in multivariate linear regression analysis after adjustment for confounding factors $(B=1.619, \mathrm{p}<0.001)$.

Conclusion: Our findings revealed that serum uric acid levels and lumbar (L2-L4) BMD were independently associated with each other in postmenopausal osteoporosis. Further studies are needed to determine the association of uric acid with osteoporosis and to address the utility of uric acid in clinical practice.

Keywords: Osteoporosis, uric acid, bone mineral density, postmenopausal women
\end{abstract}

\section{ÖZ}

Amaç: Osteoporoz, kemik kütlesi kaybı ve kırıklara yatkınlıkla sonuçlanan önemli bir halk sağlığı sorunudur. Pürin metabolizmasının son enzimatik ürünü olan ürik asitin diyabetes mellitus, hipertansiyon ve kardiyovasküler hastalıklar gibi çeşitli kronik hastalıklar üzerinde faydalı antioksidan etkilere sahip olduğunu gösteren çok sayıda kanıt vardır. Bu çalışmada postmenopozal osteoporozda serum ürik asit düzeyleri ile kemik mineral yoğunluğu (KMY) arasındaki ilişkiyi değerlendirmeyi amaçladık.

Gereç ve Yöntem: Bu çalıșma Bolu Abant İzzet Baysal Eğitim ve Araștırma Hastanesi, Fizik Tedavi ve Rehabilitasyon Kliniğinde yapıldı. Ocak 2019 ve 2020 yılları arasında çift-enerjili X-şsını absorbsiyometri (DEXA) incelemesi olan ve serum ürik asit düzeyleri kaydedilmiş olan 1200 postmenopozal kadının tıbbi kayıtları retrospektif olarak tarandı. Sistemik hastalıkları olan veya kemik metabolizmasını veya ürik asit düzeylerini etkileyen ilaç alan bireyler dışlandıktan sonra toplamda 92 osteoporozlu ve 399 sağllklı birey çalışmaya dahil edildi. Tüm bireylerde KMY, femur boynu ve lomber vertebra (L2-4) T skoru, serum glukoz, AST, ALT, kreatinin, alkalen fosfataz, kalsiyum, fosfor, parathormon ve total protein düzeyleri kaydedildi.

Bulgular: Serum ürik asit konsantrasyonları, osteoporoz grubunda kontrol grubuna göre anlamlı derecede düşük bulundu [4.65 (2.40-7.80)-5.20 (3.809.40); $\mathrm{p}<0.001$, sırasıyla]. Korelasyon analizinde ürik asit anlamlı bir şekilde açlık kan şekeri $(\mathrm{r}=0.129, \mathrm{p}=0.004)$, kreatinin $(\mathrm{r}=0.374, \mathrm{p}<0.001)$, kalsiyum $(\mathrm{r}=0.201, \mathrm{p}<0.001)$, toplam protein $(\mathrm{r}=0.123, \mathrm{p}=0.006)$ ve tiroid uyarıcı hormon $(\mathrm{TSH})(\mathrm{r}=0.108, \mathrm{p}=0.017)$ ile iliskili idi. Korelasyon analizi ürik asit ile L2-L4 KMY arasında anlamlı ve pozitif bir korelasyon olduğunu ortaya koydu $(r=0.255, \mathrm{p}<0.001)$. Çoklu doğrusal regresyon analizinde karıştırıcı faktörlerin etkisi arındırıldıktan sonra L2-L4 KMY ürik asit ile bağımsız olarak ilişkili bulundu $(\mathrm{B}=1.619, \mathrm{p}<0.001)$.

Sonuç: Bulgularımız, postmenopozal osteoporozda serum ürik asit düzeyleri ve lomber (L2-L4) KMY’nin bağımsız ilişkili olduğunu ortaya koydu. Ürik asit ile osteoporoz arasındaki ilişkiyi belirlemek ve ürik asidin klinik uygulamadaki kullanımını değerlendirmek için daha fazla çalışmaya ihtiyaç vardır.

Anahtar kelimeler: Osteoporoz, ürik asit, kemik mineral yoğunluğu, postmenopozal kadın 


\section{INTRODUCTION}

Osteoporosis is a metabolic bone disease causing reduced bone mass and degradation of bone microarchitecture resulting in bone fragility and increased fracture risk (1). The bone remodeling process occurs with equilibrium between osteoclasts and osteoblasts. Cytokines emerging during this cycle increase osteoclastic activity and lower osteoblastic activity (2). Osteoporosis development is observed in the elderly and those with diseases involving systemic inflammation (3).

Uric acid occurs as the final product of purine metabolism, especially in the liver. Mean serum uric acid levels vary according to sex, but are higher in males (4). Uric acid found in tissues may have crystal or soluble structure according to properties and may have antioxidant or prooxidant features (5). Some studies in the literature have reported hyperuricemia is associated with inflammation and plays a role in osteoporosis pathogenesis (6). Additionally, it was associated with gout, metabolic syndrome and cardiovascular diseases due to prooxidant features (7). Furthermore, there are publications stating it has protective effect against diseases with chronic inflammation like osteoporosis and Alzheimer disease $(8,9)$. When the literature is investigated, there are contradictory results about the correlation between serum uric acid levels and osteoporosis. In our study we aimed to investigate the correlation between serum uric acid levels and bone mineral density (BMD) in women with postmenopausal osteoporosis.

\section{MATERIAL AND METHOD}

This retrospective study was carried out at the Bolu İzzet Baysal Physical Medicine and Rehabilitation Training and Research Hospital, Department of Physical Medicine and Rehabilitation. The study protocol abided by the principals of the Helsinki Declaration. Electronic records of 1200 postmenopausal women between January 2019 and 2020 who had dual energy X-ray absorptiometry (DEXA) examination were analyzed retrospectively. Participants with a T score $\leq-2.5$ were defined as osteoporosis and included in the osteoporosis group. Control subjects were selected among healthy individuals who were referred for routine checkup with a T score of $>-2.5$ on DEXA examination. Patients using medications affecting bone metabolism were excluded from the study. Participants with systemic diseases such as liver and renal disease, diabetes mellitus, thyroid and parathyroid disease, gout, cancer, inflammatory disease, acute and chronic infectious diseases were also excluded from the study. In total, 92 individuals with osteoporosis and 399 healthy individuals who had $\mathrm{BMD}$ and uric acid, glucose, aspartate aminotransferase
(AST), alanine aminotransferase (ALT), creatinine, alkaline phosphatase, calcium $(\mathrm{Ca})$, phosphate $(\mathrm{P})$, parathormone $(\mathrm{PTH})$, albumin and total protein measurements were included in the study. BMD and T scores of femur neck (F neck) and lumbar spine (L2-L4), glucose, AST, ALT, creatinine, alkaline phosphatase, Ca, $\mathrm{P}, \mathrm{PTH}$, albumin and total protein were all recorded. Menopause was defined as the loss of menstruation for the last 12 months.

\section{Statistical analysis:}

SPSS 25.0 program (Armonk, NY: IBM Corp.) was used for statistical analysis. Distributions were tested for normality using the Shapiro-Wilk test. Variables were analyzed with Mann Whitney U test since they were distributed non-homogeneously. Data were presented as median (min, max). The relationship between plasma uric acid and other variables was investigated by Spearman correlation analysis. Multivariate linear regression analysis was performed to investigate the association of serum uric acid with clinical and laboratory parameters. $\mathrm{P}$ values less than 0.05 were considered statistically significant for all statistical analyses.

\section{RESULTS}

The median age of the group was $64.00(40-80)$ years, and it was comparable between the osteoporosis and control group. There were no differences between the two groups with regards to AST, Ca, P, 25-hydroxyvitamin D $(25(\mathrm{OH}) \mathrm{D}), \mathrm{PTH}$, albumin, total protein and thyroid stimulating hormone (TSH). The baseline characteristics of the study population are summarized in Table 1. The average serum uric acid concentration was $5.33(2.40-9.40) \mathrm{mg} / \mathrm{dl}$ and was significantly lower in the osteoporosis group compared with the control group [4.65 (2.40-7.80) vs. 5.20 (3.80-9.40); $<<0.001$, respectively] (Table1). Comparison of serum uric acid between patients with osteoporosis and healthy controls is shown in Figure 1. In correlation analysis, uric acid was significantly associated with age $(\mathrm{r}=0.167$, $\mathrm{p}<0.001)$, creatinine $(\mathrm{r}=0.374, \mathrm{p}<0.001)$, fasting blood glucose $(\mathrm{r}=0.129, \mathrm{p}=0.004), \mathrm{Ca} \quad(\mathrm{r}=0.201, \mathrm{p}<0.001)$, total protein $(\mathrm{r}=0.123, \mathrm{p}=0.006)$ and TSH $(\mathrm{r}=0.108$, $\mathrm{p}=0.017$ ). Correlation analysis revealed a significant but weak positive correlation between uric acid and L2-L4 BMD ( $\mathrm{r}=0.255, \mathrm{p}<0.001)$ (Table 2). Variables correlated with uric acid in correlation analysis were included in multivariate linear regression analysis. L2L4 BMD ( $\mathrm{B}=1.449, \mathrm{p}<0.001)$, age $(\mathrm{B}=0.018, \mathrm{p}=0.007)$, $\mathrm{Ca}$ $(\mathrm{B}=0.279, \mathrm{p}=0.002)$ and creatinine $(\mathrm{B}=2.358, \mathrm{p}<0.001)$ were found to be independently associated with serum uric acid after adjustment for confounding factors (Table 3). F neck BMD was not related with uric acid in multivariate regression analysis after adjustment for confounding factors. 


\begin{tabular}{|c|c|c|c|}
\hline & Osteoporosis $(\mathrm{n}=92)$ & Controls $(n=399)$ & $\mathbf{P}$ \\
\hline Age, years & $65.55(49-85)$ & $64.28(40-87)$ & 0.156 \\
\hline Uric Acid, mg/dL & $4.65(2.40-7.80)$ & $5.20(3.80-9.40)$ & $<0.001$ \\
\hline Glucose, mg/dL & $92(65-234)$ & $94(26-279)$ & 0.069 \\
\hline ALT, U/L & $15(5-51)$ & $16(5-87)$ & 0.147 \\
\hline AST, IU/L & $19(3-74)$ & $19(9-85)$ & 0.575 \\
\hline Creatinine, $\mathrm{mg} / \mathrm{dL}$ & $0.77(0.58-1.23)$ & $0.80(0.54-2.13)$ & 0.072 \\
\hline Alkaline Phosphatase, U/L & $71(24-177)$ & $68(21-169)$ & 0.319 \\
\hline $\mathrm{Ca}, \mathrm{mg} / \mathrm{dL}$ & $9.40(8.10-13.20)$ & $9.40(7.60-11.90)$ & 0.346 \\
\hline $\mathrm{P}, \mathrm{mg} / \mathrm{dL}$ & $3.70(2.60-5.70)$ & $3.80(2.10-5.90)$ & 0.126 \\
\hline $25(\mathrm{OH})$ Vitamin D, ng/dL & $16.81(4.40-84.84)$ & $15.93(3.16-96.49)$ & 0.522 \\
\hline PTH, pg/mL & $55.70(14.90-215.60)$ & $51.60(14.20-220.20)$ & 0.411 \\
\hline Albumin, g/L & $40.15(30.10-46.90)$ & $39.90(21.30-54.50)$ & 0.358 \\
\hline Total Protein, g/L & $64.65(53.10-74.80)$ & $66.20(42.40-90.60)$ & 0.256 \\
\hline TSH, uIU/mL & $1.29(0.41-9.13)$ & $1.35(0.40-9.86)$ & 0.573 \\
\hline $\mathrm{L} 2-4 \mathrm{BMD}\left(\mathrm{g} / \mathrm{cm}^{2}\right)$ & $0.76(0.60-1.45)$ & $1.01(0.79-1.82)$ & $<0.001$ \\
\hline L2-4 T Score & $-2.80(-4.10-3.00)$ & $-0.70(-2.40-4.10)$ & $<0.001$ \\
\hline F Neck T Score & $-1.50(-3.50-0.30)$ & $-0.30(-2.40-3.30)$ & $<0.001$ \\
\hline F Neck BMD $\left(\mathrm{g} / \mathrm{cm}^{2}\right)$ & $0.71(0.31-1.03)$ & $0.84(0.53-1.37)$ & $<0.001$ \\
\hline
\end{tabular}

\begin{tabular}{|c|c|c|}
\hline Variables & r value & p value \\
\hline Age & 0.167 & $<0.001$ \\
\hline Glucose & 0.129 & 0.004 \\
\hline AST & 0.014 & 0.757 \\
\hline ALT & 0.042 & 0.351 \\
\hline Alkaline Phosphatase & -0.037 & 0.416 \\
\hline Creatinine & 0.374 & $<0.001$ \\
\hline $\mathrm{Ca}$ & 0.201 & $<0.001$ \\
\hline $\mathrm{P}$ & 0.056 & 0.214 \\
\hline 25(OH) Vitamin D & -0.013 & 0.772 \\
\hline PTH & -0.003 & 0.938 \\
\hline Albumin & 0.024 & 0.602 \\
\hline Total Protein & 0.123 & 0.006 \\
\hline TSH & 0.108 & 0.017 \\
\hline L2-4 BMD & 0.255 & $<0.001$ \\
\hline F neck BMD & 0.083 & 0.065 \\
\hline
\end{tabular}

Table 3. Multivariate linear regression analysis for uric acid

\begin{tabular}{|lcc|}
\hline Variables & B & P \\
\hline L2-L4 BMD & 1.449 & $<0.001$ \\
F neck BMD & 0.053 & 0.902 \\
Age & 0.018 & 0.007 \\
Glucose & 0.001 & 0.445 \\
Calcium & 0.279 & 0.002 \\
Total protein & 0.014 & 0.121 \\
Creatinine & 2.358 & $<0.001$ \\
\hline $\begin{array}{l}\text { Dependent variable; uric acid, independent variables; L2-L4 BMD, F neck BMD, } \\
\text { age, glucose, calcium, total protein, TSH. p }<0.05 ; \text { statistically significant, BMD; bone } \\
\text { mineral density }\end{array}$ \\
\hline
\end{tabular}

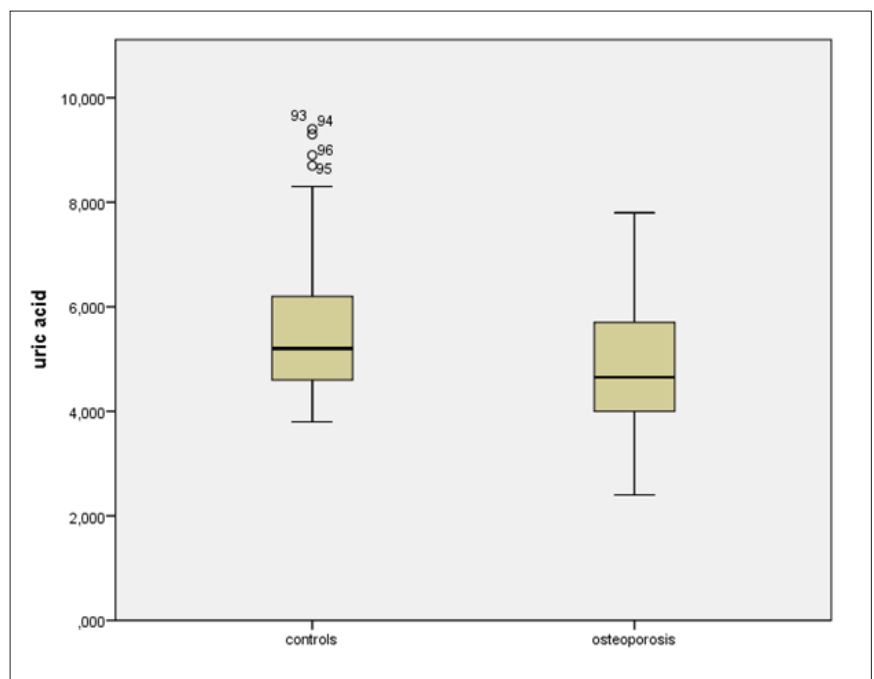

Figure 1. Comparison of serum uric acid levels between patients with osteoporosis and healthy controls

\section{DISCUSSION}

Osteoporosis is a public health concern characterized by loss of bone mass and disruption of bone architecture resulting in susceptibility to fractures especially in postmenopausal women. There is growing evidence indicating that uric acid has beneficial effects on bone metabolism. In the present study, we investigated the association of serum uric acid with bone mineral density in postmenopausal women. Our study results indicate that uric acid levels were lower in postmenopausal women with osteoporosis compared with the control group and uric acid was independently associated with BMD in the lumbar (L2-L4) spine, but not with BMD in the F neck. 
Many studies have addressed the association of uric acid and bone mineral density in the literature. However, it is remarkable that there are few studies examining this topic especially in postmenopausal women. Chen et al. (10) investigated the correlation of uric acid with BMD in patients with primary osteoporosis in both genders. They stated that uric acid was positively correlated with lumbar (L1-L4) BMD, but not with hip BMD in agreement with our study. In another study, Babaei et al. (11) investigated serum uric acid status and its association with bone mineral density in elderly people aged 60 years and older, and they reported that serum uric acid was negatively associated with osteoporosis in this population. Our study design differs between these two studies, including the patient selection; Chen at al. (10) and Babaei et al. (10) included both men and women in their study while only postmenopausal women were recruited in our study. In a study consisting of 310 healthy Indian participants, Kaushal et al. (12) categorized indiviuals into two groups based on the uric acid levels and found that height, weight and body mass index (BMI) in the group with serum uric acid $5.4 \mathrm{mg} / \mathrm{dL}$ and above were statistically significantly higher compared to the group with serum uric acid below $5.4 \mathrm{mg} / \mathrm{dL}$. They noted that alkaline phosphatase, $25(\mathrm{OH}) \mathrm{D}$, fasting blood glucose and hemoglobin A1c (HBA1c) levels were similar between the two groups. Increased uric acid levels were shown to be consistent with high BMD scores in both the lumbar region and femur neck and this effect was proposed to be due to the antioxidant properties of uric acid. A multicenter study by Lin et al. (13) including 17,735 people demonstrated statistically significant correlations between uric acid with lumbar spine BMD and lumbar spine $\mathrm{T}$ scores and $\mathrm{Z}$ scores. They reported that high uric acid levels might be protective against both osteoporosis and osteopenia. Another study including men over the age of 70 years in Australia investigated the correlation between uric acid and BMD and obtained similar results (14).

Makovey et al. (15) showed that high uric acid levels were associated with less annual loss of lumbar spine, forearm and total body BMI in studies including peri/ postmenopausal women. In contrary to many studies in the literature, this study did not show an association between uric acid with hip BMD. In our study, similar to the one by Makovey et al. (15) uric acid and hip BMD were not shown to be associated with each other. The other two studies investigating the uric acid levels and lumbar spine BMD including pre-perimenopausal and peripostmenopausal female patients in the Asian population reported similar results to our study $(16,17)$.

When the literature is investigated, studies investigating the correlation between serum uric acid levels with osteoporotic fracture development are notable. In a study by Nabipour, it was stated that higher serum uric acid levels were associated with a lower prevalence of vertebral and nonvertebral fractures in older men (14). Similarly, Chen at al. (10) reported that postmenopausal women with history of fragility fractures had significantly lower levels of uric acid compared to postmenopausal women without fragility fractures and claimed that serum uric acid might be a protective factor for bone health in primary osteoporosis. Lane et al. (18) investigated the correlation of uric acid and fracture risk in older men in the osteoporotic fractures in men (MrOS) study and they demonstrated that higher serum uric acid levels were associated with a reduction in risk of incident nonvertebral fractures despite the fact that it was not related with higher hip BMD and hip fractures. In the Rotterdam study, it was found that higher levels of uric acid were associated with a reduction in incident osteoporotic and nonvertebral fractures in both men and women in agreement with the MrOS study. It was also noted that there was no association between serum uric acid and hip or vertebral fractures. In addition, the relationship of uric acid with favorable hip bone geometry was first demonstrated in this study (19).

Although recent studies have reported that hyperuricemia could help protect against the onset of bone fractures, contradictory results are found when the literature is reviewed. In the Verona study including both female and male individuals with $4 \pm 1.2$ year follow-up, basal serum uric acid levels were not shown to be associated with new onset osteoporotic fracture development. Furthermore, they indicated that participants with higher serum uric acid levels had significantly less osteoporosis in agreement with most of the studies reported in the literature (20). In another study, Zhang et al. (21) established a rat model of experimental mild hyperuricemia and examined the relationship between uric acid and BMD. They did not find any relationship between hyperuricemic rats and normouricemic rats with respect to BMD, volume density and biomechanical properties, contrary to accumulating evidence supporting possible associations between serum uric acid levels and BMD. The cause of the contradictory results in these studies may be explained by differences in patient selection such as sex, age and ethnicity. Difference in study designs and participant numbers may also cause conflicting results. We think that from this perspective, future prospective studies are required to reveal the reasons underlying the conflicting results.

In the present study, we did not demonstrate an independent relationship between uric acid and serum levels of $25(\mathrm{OH})$ vitamin $\mathrm{D}, \mathrm{PTH}$ and P. We found that uric acid was independently and positively associated with calcium, age and creatinine in the adjustment model on regression analysis. Different from present study, Chen $\mathrm{Li}$ reported that uric acid was negatively related with $25(\mathrm{OH})$ vitamin $\mathrm{D}$, but not with $\mathrm{Ca}$ or $\mathrm{P}$ in elderly 
people with primary osteoporosis (10). In another study, Xiong also did not demonstrate any causal relationship between serum uric acid and PTH, Ca or P. Contrary to these studies, Hui at al. (22) found an independent relationship between uric acid and PTH levels in a national population study.

Our findings demonstrate a significant positive association between serum uric acid and lumbar (L2L4) BMD in postmenopausal women in agreement with studies claiming a protective effect of higher uric acid on osteoporosis. It is not clear yet whether postmenopausal women at risk of osteoporosis should be treated in the presence of asymptomatic hyperuricemia because of its protective effect on bone health. Li et al. (23) investigated serum uric acid levels and multiple health outcomes depending on review of evidence from observational studies, randomized controlled trials, and Mendelian randomization studies. They reported that a clear role for serum uric acid levels existed only for gout and nephrolithiasis.

There are, however, some limitations to this study. First, individuals in this study were included from a single tertiary hospital; thus, this may not be representative of the general population. Retrospective design and relatively small study population in osteoporosis group are the second and third limitations.

We think that our findings provide additional data on the beneficial effects of uric acid on bone mineral health in postmenopausal women. Clinical implications of serum uric levels in postmenopausal women with osteoporosis are not clear yet and need to be determined by further larger scale studies with sufficient power.

\section{ETHICAL DECLARATIONS}

Ethics Committee Approval: The study was carried out with the permission of the Bolu Abant Izzet Baysal University Noninterventional Ethics Committee (Permission granted/ date-TUEK: 16.06.2020, Number of meeting: 321, Decision number: 2020/16).

Informed Consent: Because of the study was designed retrospectively, no written informed consent form was obtained from patients.

Referee Evaluation Process: Externally peer-reviewed.

Conflict of Interest Statement: The authors have no conflicts of interest to declare.

Financial Disclosure: The authors declared that this study has received no financial support.

Author Contributions: All of the authors declare that they have all participated in the design, execution, and analysis of the paper, and that they have approved the final version.

\section{REFERENCES}

1. Varacallo MA, Fox EJ. Osteoporosis and its complications. Med Clin North Am 2014; 98: 817-31.

2. Charles JF, Aliprantis AO. Osteoclasts: more than 'bone eaters'. Trends Mol Med 2014; 20: 449-59.

3. Ginaldi L, Di Benedetto MC, De Martinis M. Osteoporosis, inflammation and ageing. Immun Ageing 2005; 2: 14.

4. Antón FM, García Puig J, Ramos T, González P, Ordás J. Sex differences in uric acid metabolism in adults: evidence for a lack of influence of estradiol-17 beta (E2) on the renal handling of urate. Metabolism 1986; 35: 343-8.

5. Sautin YY, Johnson RJ. Uric acid: the oxidant-antioxidant paradox. Nucleosides Nucleotides Nucleic Acids 2008; 27: 608-19.

6. Kim SC, Paik JM, Liu J, Curhan GC, Solomon DH. Gout and the risk of non-vertebral fracture. J Bone Miner Res 2017; 32: 230-6.

7. Genoni G, Menegon V, Secco GG, et al. Insulin resistance, serum uric acid and metabolic syndrome are linked to cardiovascular dysfunction in pediatric obesity. Int J Cardiol 2017; 249: 366-71.

8. Han W, Bai X, Wang N, Han L, Sun X, Chen X. Association between lumbar bone mineral density and serum uric acid in postmenopausal women: a cross-sectional study of healthy Chinese population. Arch Osteoporos 2017; 12: 50.

9. $\mathrm{Du} \mathrm{N}, \mathrm{Xu} \mathrm{D}, \mathrm{Hou} \mathrm{X}$, et al. Inverse association between serum uric acid levels and Alzheimer's disease risk. Mol Neurobiol 2016; 53: 2594-9.

10. Chen L, Peng Y, Fang F, Chen J, Pan L, You L. Correlation of serum uric acid with bone mineral density and fragility fracture in patients with primary osteoporosis: a single-center retrospective of 253 cases. Int J Clin Exp Med 2015; 8: 6291-4.

11. Babaei M, Shamsi R, Heidari B, Bijari A. Serum uric acid status and its association with bone mineral density in the elderly people aged 60 years and more. Int J Endocrinol Metab 2019; 17: e80780.

12. Kausal N, Vohora D, Jalali RK, Jha S. Raised serum uric acid is associated with higher bone mineral density in a cross-sectional study of a healthy Indian population Ther Clin Risk Manag 2018; 14: 75-82.

13. Lin X, Zhao C, Qin A, et al. Association between serum uric acid and bone health in general population: a large and multicentre study. Oncotarget 2015; 6: 35395-403.

14. Nabipour I, Sambrook PN, Blyth FM, et al. Serum uric acid is associated with bone health in older men: a cross-sectional population-based study. J Bone Miner Res 2011; 26: 955-64.

15. Makovey J, Macara M, Chen JS, et al. Serum uric acid plays a protective role for bone loss in peri- and postmenopausal women: a longitudinal study. Bone 2013; 52: 400-6.

16. Kim S, Jung J, Jung JH, Kim SK, Kim RB, Hahm JR. Risk factors of bone mass loss at the lumbar spine: a longitudinal study in healthy korean pre- and perimenopausal women older than 40 years. PLoS One 2015; 10: e0136283.

17.Ishii S, Miyao M, Mizuno Y, Tanaka-Ishikawa M, Akishita M, Ouchi Y. Association between serum uric acid and lumbar spine bone mineral density in peri- and postmenopausal Japanese women. Osteoporos Int 2014; 25: 1099-105.

18. Lane NE, Parimi N, Lui LY, et al. Osteoporotic fractures in men study group association of serum uric acid and incident nonspine fractures in elderly men: the osteoporotic fractures in men (MrOS) study. J Bone Miner Res 2014; 29: 1701-7.

19. Muka T, de Jonge EA, Kiefte-de Jong JC et al. The influence of serum uric acid on bone mineral density, hip geometry, and fracture risk: the rotterdam study. J Clin Endocrinol Metab 2016; 101: 1113-22. 
20. Veronese N, Bolzetta F, De Rui M, et al. Serum uric acid and incident osteoporotic fractures in old people: The PRO.V.A study. Bone 2015; 79: 183-9.

21.Zhang D, Bobulescu IA, Maalouf NM, et al. Relationship between serum uric acid and bone mineral density in the general population and in rats with experimental hyperuricemia. J Bone Miner Res 2015 ; 30: 992-9.

22. Hui JY, Choi JWJ, Mount DB, Zhu Y, Zhang Y, Cho HK. The independent association between parathyroid hormone levels and hyperuricemia: a national population study. Arthritis Res Ther 2012; 14: R56.

23. Li X, Meng X, Timofeeva $M$, et al. Serum uric acid levels and multiple health outcomes: Umbrella review of evidence from observational studies, randomised controlled trials, and Mendelian randomisation studies. BMJ 2017; 357: j2376. 